\title{
ОБЩЕСТВЕННО-ЭКОНОМИЧЕСКИЕ ИДЕАЛЫ СОЦИАЛИСТОВ И КОММУНИСТОВ В ЧАСТИ ПЛАТЕЖНО-КРЕДИТНОЙ СИСТЕМЫ И ИХ ДОСТИЖИМОСТЬ
}

\author{
(c) 2021 Лебедев Константин Николаевич \\ доктор экономических наук, профессор, профессор Департамента экономической теории \\ Финансовый университет при Правительстве Российской Федерации, Россия, Москва \\ E-mail: KNLebedev@fa.ru \\ ORCID: https://orcid.org/0000-0002-4846-8097
}

В статье с точки зрения теории нефинансовой экономики обосновывается возможность перехода от банковского товарообмена к прямому товарообмену в масштабах экономик стран уже в условиях стихийной экономики, как при прежнем банкнотном, так и при современном безналичном денежном обращении. Для этого рассматриваются товарообменные функции платежной и кредитной систем, их операторы, условия их деятельности при банковском и прямом товарообмене, показываются выгоды от перехода к прямому обмену как для как участников обмена, так и для внешних операторов платежно-кредитной системы. Доказывается, что в СССР к середине 1950-х гг. функционировала банковская система, утратившая свой финансовый характер, и страна была близка к полной отмене банковской системы, но этому помешал последовавший после смерти И.В.Сталина в 1953 г. отказ от дальнейшего совершенствования системы централизованного управления экономикой и взятый курс на ее последовательный демонтаж.

Ключевые слова: нефинансовая экономика, функции платежной системы, функции кредитной системы, прямой многосторонний товарообмен, экономика без банков.

В наших работах было показано, что социально-экономическим идеалом авторов социалистических и коммунистических учений в части системы ресурсообеспечения «капитал» были нефинансовые капитальные системы, присущие таким формам крупного хозяйствования, как классическое государственное предприятие (госпредприятие, централизованно управляемое государством) и классический производственный кооператив (кооператив, учредители которого целиком образуют его трудовой коллектив), трактуемые как нефинансовые в связи с тем, что учредители соответствующих предприятий взамен учредительских взносов получают в собственность имущество предприятия, т.е. полный товарный эквивалент взносов. При этом социалистами и коммунистами предполагалось ликвидировать в экономике такие формы предприятия, как акционерного общество (AО) и общество с ограниченной ответственностью (ООО), которым присущи нефинансовые капитальные системы, трактуемые как таковые в связи с тем, что учредители АО и ОО (когда весь трудовой коллектив предприятия, включая топ-менеджеров, состоит из наемных работни- ков) взамен учредительских взносов получают в собственность лишь свидетельства о взносах, не имеющие эквивалентной взносам внутренней стоимости. Нами было показано, что эти преобразования отношений собственности являются вполне обоснованными с точки зрения теории нефинансовой экономики, в духе которой написана данная статья, поскольку нефинансовые капитальные системы, как и в общем случае сравнения нефинансов с финансами, являются более эффективными, чем финансовые капитальные системы [10, с. 257],

Как выясняется, и в части таких систем ресурсообеспечения, как платежная и кредитная системы, социально-экономическим идеалом авторов социалистических и коммунистических учений были нефинансовые платежнокредитные системы общенационального масштаба, представляющие собой системы прямого многостороннего товарообмена. Нами уже рассматривались локальные сети прямого, т.е. безденежного, многостороннего товарообмена, и было отмечено, что их платежные системы являются нефинансовыми в силу того, что платежным средством в них выступают предметы, 
принимаемые в оплату по стоимости их изготовления [4, с. 97], т.е. имеющие внутреннюю стоимость, равную номиналу, в данном случае сами товары, переданные участниками прямого обмена другим его участникам. Кредитные системы этих сетей являются нефинансовыми потому, что заемщик получает и возвращает кредит, в данном случае товарами, по договорам поставки товаров, а не по кредитному договору (см. ниже). При этом социалистами и коммунистами предполагалось полная ликвидация банковской платежно-кредитной системы, банкнотной или безналичной - в зависимости от того, какие деньги господствовали в эпоху, применительно к которой планировалась ликвидация. Эти преобразования также являются вполне обоснованными с точки зрения теории нефинансовой экономики, поскольку нефинансовые, в том числе бартерные, платежно-кредитные системы являются более эффективными, чем финансовые, что также было показано в наших работах [4, с. 109].

Рассмотрим наиболее описанные системы прямого многостороннего товарообмена, разработанные социалистом Робертом Оуэном и идеологом анархизма Пьера-Жозефа Прудоном. Это, действительно, были сети безденежного многостороннего товарообмена, признаком которых является, прежде всего, соглашение их участников о взаимном обмене товарами без участия денег. Как писал об Обменных банках Р. Оуэна видный советский специалист в области денег и кредита 3.В.Атлас, в 1832 г. Р. Оуэн обратился от имени «Института справедливого обмена трудящихся классов» к широкой публике, предложив организовать обмен товарами так, чтобы каждый отдавал свою ценность, выраженную в труде, за равную ценность, выраженную в труде, без посредства денег, и вскоре Институт начал функционировать [2, с. 194]. Как писал М.И.Туган-Барановский о Народном банке П.Ж. Прудона, этот банк должен был обслуживать общество производителей товаров всякого рода, члены которого обмениваются производимыми продуктами друг с другом [15]. Банк был учрежден в 1849 г., но не заработал из-за судебных преследований П.-Ж. Прудона [11]. При этом обе системы прямого товарообмена задумывались как общенациональные, призванные полностью заменить денежный товарообмен. Об этом говорят планы Р. Оуэна полностью ликвидировать денежную систему: «До настоящего време- ни ошибочная денежная система была во всем мире причиной многих пороков и горя, но это новое совершенное средство обращения послужит причиной добродетели и счастья для всего человеческого рода» [17, с. 296-297]. Об этом говорят и его планы включить в сферу своего товарообменного предприятия все товары, производимые в обществе: «...Чтобы быть совершенным, оно должно обладать такими разнообразными товарами, которые только можно найти на товарном рынке, а когда Банк этого достигнет, то участники дела распрощаются с бедностью и горем» [17, с. 303]. В уставе Народного банка записано, что все граждане приглашаются стать его участниками [3, с. 400], а цель общества будет достигнута, когда в него войдут все производители и потребители [3, с. 402]. Но о масштабности планов анархиста лучше всего говорит оценка самим П.-Ж. Прудоном характера и последствий задуманного им предприятия: «Я начинаю дело, равному которому не было и не будет в мире. Я хочу изменить основание общества, повернуть ось цивилизации, сделать так, чтобы мир, который по воле Божества движется с запада на восток, начал двигаться, по воле человека, с востока на запад» [19, с. 100].

При этом авторы социалистических и коммунистических банковских реформ делились на авторов, которые планировали полную замену банковских систем товарообмена уже в эпоху стихийной экономики (те же Р. Оуэн и П.-Ж. Прудон), и авторов, которые считали ее возможной только после перехода к плановой экономике, причем из них одна часть считала возможным введение прямого товарообмена уже на стадии социализма, а другая - только после перехода к коммунизму. Следует отметить, что основная масса банковских реформ задумывалась для условий банкнотного обращения, в связи с чем знаки прав на получение товаров от общества, необходимые для обеспечения эквивалентности товарообмена между отдельными участниками и остальным обществом, также имели наличную бумажную форму.

Комплексным примером автора их второй группы выступает К. Маркс. В «Критике политической экономии» (написано в 1859 г.) он критикует проект английского социалиста Джона Грея по замене в буржуазном обществе денег «рабочими деньгами», утверждая, что этого нельзя сделать без замены всех остальных условий буржуазного производства, в доказательство 
этого отмечает, что к такой замене незаметно для самого себя склоняется сам Грей. Как пишет К. Маркс, «...если внимательно приглядеться к деятельности его банка, то можно обнаружить, что он не только одной рукой принимает товары, а другой выдает свидетельства на доставленный труд, но и регулирует самое производство». Здесь же К. Маркс намекает, на то, что деньги будут опосредовать товарный обмен и при социализме [12, с. 69-70]. В «Критике Готской программы» (написано в 1875 г.) К. Маркс пишет, что в коммунистическом обществе, только что вышедшем из капиталистического общества, производитель «...получает от общества квитанцию в том, что им доставлено такое-то количество труда (за вычетом его труда в пользу общественных фондов), и по этой квитанции он получает из общественных запасов такое количество предметов потребления, на которое затрачено столько же труда. То же самое количество труда, которое он дал обществу в одной форме, он получает обратно в другой форме» [13, с. 18]. Как мы видим, «поздний» К. Маркс считал возможным прямой товарообмен уже при социализме.

Очевидно, система прямого товарообмена, задуманная малоизвестным современному читателю американским писателем-утопистом Эдвардом Беллами в книге «Взгляд назад» (1888), относилась к коммунизму. Кстати, книга Э.Беллами, в которой описано соответствующее общество будущего, пользовалась огромной популярностью в конце XIX в.- уже к концу 1889 г. она была переведена и издана в 20 странах, в том числе в России (под названием «Через 100 лет»), ее поклонниками были у нас Л.Толстой, М.Горький и группа большевиков во главе с А. Богдановым, а в 2011 г. в Екатеринбурге был открыт Памятник пластиковой карте, идею которой выдвинул Э.Беллами [20]. В государстве Беллами, как пишет М.И.Туган-Барановский, каждому взрослому мужчине и женщине открывается кредит на одинаковую сумму и выдается соответствующая именная кредитная книжка, в которой обозначена сумма кредита. При приобретении предметов потребления в государственных магазинах с открытого в книжке кредита списывается цена купленного предмета, также обозначенная в долларах. При этом обозначение всех цен в долларах имеет символическое значение, так как реально доллара как предмета определенной ценности не существует, и денежная единица является лишь единицей счета [19, с. 76].
Цель настоящей статьи состоит в том, чтобы показать, что переход в общенациональном масштабе к прямому многостороннему товарообмену возможен уже в стихийной экономике, причем в условиях как устаревшего банкнотного, так и современного безналичного банковского товарообмена, а тем более - на первой стадии плановой экономики - при социализме. Для ее достижения предполагается решить следующие задачи: рассмотреть различия между товарообменом при банковском и прямом товарообмене, рассмотреть конечные товарообменные функции платежной и кредитной систем, рассмотреть операторов платежной и кредитной систем при банкнотном и безналичном денежном обращении, рассмотреть их операторов при переходе к прямому товарообмену и изменение условий их деятельности, показать большую приемлемость безденежных общенациональных платежной и кредитной систем как для участников обмена, так и для их внешних операторов, показать, что в середине 1950-х гг. в СССР фактически функционировала система прямого товарообмена, причем страна была близка к отмене и формальной банковской системы, но этому помешал отказ от курса на укрепление системы централизованного управления экономикой после смерти И.В. Сталина в 1953 г.

При банковском обмене его участники вначале обменивают (или им обменивают) права на получение товаров от общества (возникающие в результате передачи обществу товаров, уступки кем-то товарных прав и разрешения на получение товаров от общества в кредит), уступленные кому-то товарные права и переданные обществу в погашение взятого у него товарного кредита товары на банковские деньги, а затем посредством этих денег используют товарные права (путем покупки товаров), передают уступленные товарные права (путем, например, уплаты налогов) и подтверждают погашение полученного от общества товарного кредита (путем погашения банковских кредитов). При прямом обмене права на получение товаров от общества используются для их получения непосредственно, уступка кому-то товарных прав осуществляется непосредственно, разрешенный товарный кредит берется у общества и гасится непосредственно товарами.

Платежная система была определена нами как система, функцией которой в товарообмене является обеспечение участников обмена рас- 
четными (платежными) средствами и обеспечение их использования ими [4, с. 97]. Ее второй функцией является обеспечение того, чтобы участники обмена не использовали прав на получение товаров от общества в объеме, большем, чем имеющиеся у них товарные права. Функциями кредитной системы в товарообмене являются: обеспечение платежной системы правами на получение товаров от общества в порядке кредита в размере общественной потребности в кредите, соответствующей стоимости инвестиционных проектов с гарантированным возвратом обществу товарами полученных под них товарных кредитов, обеспечение возврата заемщиками товарных кредитов в определенные сроки. Это - конечные товарообменные функции платежной и кредитной систем, проявляющиеся при прямом товарообмене непосредственно, а при банковском - опосредовано через движение денег.

При банкнотном обмене оператором банковской (использующей банковские деньги) платежной системы в обеих функциях выступают сами участники обмена (т.е. у нее полностью внутренний оператор). Отдельного участника обмена обеспечивают банкнотами другие участники в обмен на полученные от него товары и уступая ему товарные права или он сам, получая банкноты в обмен на разрешение оператора кредита получить от общества товары в кредит. Отдельный участник обмена использует банкноты, отдавая их другим участникам в обмен на получаемые от них товары и уступая им товарные права или отдавая их оператору кредита в подтверждение возврата товарного долга обществу. Вторая функция платежной системы решается участниками обмена (и оператором кредита) путем обеспечения обязательной передачи банкнот взамен полученного товара, уступленного товарного права или в подтверждение выдачи/погашения товарного кредита. Тогда остаток банкнот на руках участника будет характеризовать остаток его товарных прав, и он не сможет израсходовать товарных прав больше, чем у него осталось, так как банкнот нельзя потратить больше, чем есть в наличии.

При банкнотном обмене оператором кредита является внешний оператор (сами банки). Он обеспечивает платежную систему платежными средствами, которыми выступают банкноты, в порядке их обмена на выдаваемые права на получение товаров от общества в кредит, а также обеспечивает возврат обществу пользующимися спросом товарами полученных от него товаров заемщиками путем требования возврата ему банкнот, полученных ими от общества за эти товары.

При безналичном обмене оператором банковской платежной системы выступает внешний оператор (сами банки). Он обеспечивает участников обмена безналичными деньгами, записывая в кредит их лицевых счетов суммы, причитающиеся им за переданные обществу товары, за уступленные в их пользу товарные права и в порядке кредитов. Вторая функция платежной системы реализуется внешним оператором путем обязательного исполнения расчетных поручений и списания по дебету лицевых счетов безналичных денег в пределах их кредитового остатка, в связи с чем сумма использованных участниками обмена прав на получение товаров от общества не может быть больше имеющихся на это прав.

При безналичном обмене оператором кредитной системы также выступает внешний оператор (сами банки). Он обеспечивает платежную систему безналичными деньгами в порядке их обмена на выдаваемые права на получение товаров в кредит, обеспечивает возврат обществу пользующимися спросом товарами полученных от него товаров заемщиками путем требования возврата ему безналичных денег, полученных ими от общества за эти товары.

При замене прямым обменом банкнотного обмена оператором платежной системы, как и раньше, выступают участники обмена (т.е. ее оператор продолжает оставаться внутренним). Только теперь участников обмена средствами платежа обеспечивают товаропроизводители, производящие ходовые товары (сами себя и тех, кому они уступили товарные права).

Вторая функция платежной системы осуществляется участниками прямого обмена (и кредитным оператором) путем обеспечения обязательной передачи взамен полученного товара, уступленного товарного права или в подтверждение выдачи/погашения товарного кредита уже не банкнот, а специальных наличных знаков прав на получение товаров от общества, получаемых от кредитного оператора. Тогда остаток знаков на руках у участника будет характеризовать остаток его товарных прав, и он не сможет израсходовать товарных прав больше, чем их у него имеется, так как знаков нельзя 
потратить больше, чем есть в наличии. Данные знаки не являются платежным средством, а являются всего лишь средством контроля за эквивалентностью товарообмена между отдельными субъектами экономики и остальным обществом. Эти знаки, в отличие от денег, не образуют активов участников обмена (расчетного счета, кассы и т.д.). Такие активы образуют переданные обществу товары, уступленные в пользу участника права или права на получение товаров в кредит, предоставленные кредитным оператором.

При замене прямым обменом банкнотного обмена оператором кредита продолжает быть внешний оператор, роль которого могут исполнять прежние коммерческие банки (с учетом принципиальных изменений в условиях их работы - см. ниже). Но теперь оператор кредита обеспечивает платежную систему не средствами платежа в виде банкнот, а сразу разрешениями на получение от общества товаров в кредит в виде тех же знаков товарных прав. Оператор кредита обеспечивает возврат обществу пользующимися спросом товарами полученных от него товаров заемщиками путем требования возврата ему знаков товарных прав, полученных заемщиком от общества при передаче ему этих товаров.

Важно отметить, что условия деятельности внешнего оператора кредита по выдаче разрешений на получение товаров от общества в кредит в размере общественной потребности в нем при переходе от банкнотного обмена к прямому обмену принципиально меняются. Раньше оператор кредита (в лице отдельных банков) был крайне стеснен в исполнении данной функции. Вследствие того, что он должен был выдавать разрешения на получение товарного кредита от общества банкнотами, он был вынужден предварительно привлекать средства во вклады и в виде заемных средств (в случае необходимости) и/или формировать значительный собственный капитал, в том числе как средство привлечения вкладчиков, для которых значительная величина капитала банка выполняет роль гарантии возврата вкладов. Таким образом, разрешаемый оператором посредством банкнот кредит был ограничен имеющимися у него финансовыми ресурсами. Далее, уже в этих рамках оператор должен был ограничивать кредит банкнотами исходя из необходимости избежать банкротства, не обеспечив свободный размен выпущенных им в обращение банкнот на звонкую монету и возврат ею вкладов и займов (до появления центральных банков (ЦБ)) или не обеспечив возврат таковых банкнотами ЦБ (после появления ЦБ). И в этих рамках он должен был сокращать кредитование на величину риска невозврата кредитов. При этом оператор кредита был ограничен еще и в способности адекватно оценивать инвестиционные проекты, так как представлял собой несколько, а то и множество, конкурирующих коммерческих банков и получал доход в виде процента от суммы выданных кредитов. Первое обстоятельство не позволяло иметь адекватные исследовательские возможности для проверки проектов, а второе - побуждало закрывать глаза на недостатки проектов, что приводило к невозврату товарных кредитов обществу и, соответственно, банкнотных кредитов оператору кредита.

В условиях прямого обмена оператор кредита всего лишь выдает разрешения на получение товарных кредитов от общества в виде прав на получение от него товаров, т.е. не испытывает ограничений в своей кредитной работе со стороны ресурсов, необходимых для ведения кредитной деятельности банкам, рисков неисполнения обязательств перед владельцами банкнот и вкладов и рисков невозврата кредитов, которые несут банки. Теперь кредит выдается (с разрешения оператора) самим обществом (сразу товарами), ресурсы которого неограничены, и оно же, а не кредитный оператор, непосредственно несет потери от невозврата (товарных) кредитов.

При этом оператор кредита имеет все возможности для адекватной оценки инвестиционных проектов, так как представляет собой единую организацию в масштабах страны (в ее головной орган может быть превращен бывший центральный банк, а в ее низовые органы - прежние коммерческие банки), в связи с чем обладает необходимыми исследовательскими возможностями, а также получает доход не в виде процента от разрешенных кредитов, а в виде части прибыли от реализованных (т.е. успешных) инвестиционных проектов.

При замене прямым обменом безналичного обмена оператором платежной системы при осуществлении первой функции становятся сами участники обмена, так как теперь их обеспечивают средствами платежа товаропроизводители, производящие ходовые товары (сами себя и тех, кому они уступили товарные права). Ее же оператором при осуществлении второй 
функции продолжает оставаться внешний оператор, который может быть создан из прежних коммерческих банков. Он исполняет вторую функцию путем обязательного зачисления в кредит открытых у него лицевых счетов участников товарообмена полученных ими прав на получение товаров (в обмен на переданные обществу товары, в порядке уступки товарных прав или в порядке получения разрешений на товарный кредит) и обязательного списания с лицевых счетов участников обмена (по дебету) использованных ими прав на получение товаров от общества (в виде получения товаров, уступки товарных прав или возврата этих прав кредитному оператору) в пределах кредитового остатка лицевого счета, в связи с чем участники и не могут истратить прав больше, чем имеют. Важно отметить, что документы, используемые в качестве основания для осуществления операций по лицевым счетам участников обмена, теперь являются «неденежными», например зачисление/списание прав, получаемых/расходуемых в операциях купли/продажи товаров, осуществляется на основании предоставляемых оператору участниками обмена документов о приеме/передаче товаров. При этом в учете клиентов счета расчетов объединяются в единый счет с расчетным счетом. Как и при безналичном банковском обмене, клиенты отражают в своем учете товарные расчеты на основании выписок оператора из их лицевых счетов по учету товарных прав.

При замене прямым обменом безналичного обмена оператором кредита продолжает оставаться внешний оператор, который также может быть создан на базе прежних коммерческих банков. При этом его работа соответствует работе оператора кредита при замене банкнотного обмена, с той разницей, что права на получение товаров от общества выдаются и принимаются назад в безналичной форме.

Внешний оператор платежно-кредитной системы, созданный из прежних коммерческих банков, может продолжать именоваться банковской системой, но это будет уже формальная банковская система.

При этом перемена условий деятельности внешнего оператора кредита по выдаче разрешений на получение товаров от общества в кредит несколько отличается от той, которая имеет место при замене прямым обменом банкнотного обмена. Дело в том, что при безналичном обмене банки хранят резервы в соответствии с уста- новленными нормативами на счетах, открытых в ЦБ, используют эти счета для осуществления межбанковских переводов и получают (гасят) кредиты от ЦБ зачислениями (списаниями) на эти счета. В этих условиях возможности кредитования банками клиентов безналичными (и в сохраняющейся части - наличными) деньгами в значительной мере зависят от расположения к банкам ЦБ, а также от его политики в отношении коммерческого кредитования. При переходе в этих условиях к прямому обмену внешний оператор кредита полностью освобождается от соответствующих связей с ЦБ и от всякой зависимости от него, прежде всего в связи с тем, что центральный банк как кредитно-депозитное учреждение для коммерческих банков, или как «кредитор в последней инстанции», ликвидируется, в результате чего счета комбанков в ЦБ превращаются в счета межбанковских расчетов, которые теперь могут иметь отрицательное сальдо, а роль ЦБ в функционировании платежной системы сводится к работе центра межбанковских расчетов, без которого бывшие банки также могут обойтись, направляя документы по межбанковским перечислениям товарных прав непосредственно друг другу. При этом, однако, центральный банк может быть превращен в головной орган единого внешнего оператора кредита. Центральный банк ликвидируется как элемент абсолютно ненужной теперь системы денежного опосредования получения заемщиками товарных кредитов от общества и их погашения передаваемыми ему товарами, поскольку такое кредитование теперь осуществляется напрямую.

С точки зрения теории нефинансовой экономики возможность замены прямым товарообменом банковского товарообмена обосновывается большей эффективностью платежно-кредитной системы первого по сравнению со вторым. Она более приемлема для участников обмена. Ее платежные средства более доступны, так как создаются самими товаропроизводителями, т.е. их не нужно, как раньше, у кого-то выменивать. Ее кредит более доступен, так как выдается всем заемщикам, представившим адекватные проекты. Платежи за ее услуги крайне незначительны, поскольку ее функционирование не требует тех колоссальных ресурсов, которые нужны для функционирования банковской системы, и соответствующих расходов на их привлечение. Она более безопасна для клиентов, так как у нее нет 
проблем банков, из-за которых она будет вынуждена остановить расчеты, лишить клиентов платежных средств, проекты, под которые выдается кредит, проходят тщательную экспертизу со стороны высококомпетентного и бесстрастного органа. Безденежная платежно-кредитная система более приемлема и для тех, кто хочет стать ее внешним оператором. Она более доступна, хотя бы потому, что не требует вложения в бизнес существенного капитала. Она более экономична, хотя бы потому, что у оператора отсутствуют издержки взаимодействия с прежним банковским надзором. Она более безопасна, так как оператор действует вне поля прежних банковских рисков. Безденежная платежно-кредитная система более приемлема и для общества в целом, так как оно лишается необходимости содержать национальный денежный капитал, который сейчас является «мертвым грузом» общества, и может жить без проблем, порождаемых функционированием банковской кредитной системы, например надувания кредитных «пузырей».

Заметим, что практические подтверждения традиционного представления о безальтернативности в целом банковской системы в рыночной (стихийной) экономике всегда основывались на итак страдавших алогичностью доказательствах и подтверждениях «утопичности» проектов Р. Оуэна и П.-Ж. Прудона. В настоящее время они становятся неактуальными, поскольку, в подтверждение сказанного теорией нефинансовой экономики, что в мире в последние десятилетия идет процесс вытеснения финансов нефинансами, исследователями установлено, что в странах мира, прежде всего развитых, начиная с 1980-х гг. идет успешный процесс распространения локальных сетей безденежного многостороннего товарообмена, подобных Обменным банкам Р.Оуэна, а именно банков времени, и Народному банку П.-Ж. Прудона, а именно товарообменных сетей LETS [6]. Так что и без того вызывающий сомнения тезис о невозможности трудовых цен в стихийной экономике наталкивается на очевидное практическое опровержение.

Выше было показано, что введение прямого товарообмена обмена на базе традиционной банковской системы качественно трансформирует ее функционирование. Банковская система, применяя в работе с клиентами техники, схожие с прежними, т.е. еще сохраняя свою форму, уже утрачивает финансовый характер, становится формальной банковской системой. Как следует из изложенного выше, современная безналичноденежная банковская система реально утрачивает свой финансовый характер в результате лишения центробанка положения кредитора в последней инстанции. Тогда деньги, как безналичные, так и наличные, автоматически превращаются в знаки товарных прав, а передаваемые обществу товары - в платежные средства, и даже не имеет значения, что банки продолжают осуществлять безналичные операции на основе денежных документов, поскольку последние привязаны к товарным документам или характеризуют ту же уступку или возврат товарных прав, а в бухгалтерском учете предприятий и организаций продолжают фигурировать счета по учету денежных средств (расчетный счет, касса и др.). Эти теперь уже «архаизмы» могут быть устранены одним инструктивным письмом Госбанка и Минфина так же легко, как Советская власть уничтожила буквы-ископаемые типа «ять».

Покажем, что, исходя из сказанного выше, безденежная платежно-кредитная система фактически функционировала в СССР, в частности, в середине 1950-х гг. Прежде всего, Государственный банк СССР не был кредитором в последней инстанции. Он не занимался кредитованием банков, непосредственно обслуживавших клиентов, а кредитовал сразу клиентов банковской системы, поскольку сам обслуживал основную массу организаций, выступавших ее клиентами. Госбанк не кредитовал «спецбанки», которые также были его клиентами, поскольку в этом не было никакой нужды. Спецбанкам (Банк бля внешней торговли, 4 банка долгосрочных вложений и Сберегательные кассы) не нужно было соблюдать никаких резервных требований (бессмысленных в экономике с плановым обменом), и они не нуждались ни в какой помощи, так как ничто не могло остановить их деятельность, даже масштабные невозвраты кредитов (т.е. они фактически выдавали разрешения на получение товарных кредитов от общества). Формирование их ресурсов за счет кредитов Госбанка не предусматривалось. В частности, ресурсы четырех банков долгосрочных вложений формировались за счет средств, получаемых из бюджета, и накоплений самих хозяйственных организаций (части их амортизационных отчислений и прибылей), да еще и использовались главным образом на безвозмездной основе [18, с. 10-17], что 
делает невозможным формирование их ресурсов за счет кредитов в соответствующей части. В расходной части кредитного плана Госбанка не было кредитов, предоставляемых спецбанкам, в частности все кредиты Госбанка по видам кредитов были представлены краткосрочными кредитами, предоставляемыми Госбанком обслуживаемым им предприятиям (под сезонные запасы и затраты, под расчетные документы в пути, на временные нужды) [18, с. 34]. Как было показано выше, отсутствие у ЦБ функции кредитора в последней инстанции фактически превращает банковскую систему в оператора безденежного обмена, а банковские (наличные и безналичные) деньги - в простые знаки прав на получение товаров от общества.

Подтверждением последнего является отсутствие в СССР трактовки безналичных денег как денег. Это видно из первого учебника политической экономии социализма (1954), сформированного фактически под руководством И.В.Сталина. Как писали его авторы, «советские деньги обращаются в виде банковских билетов (банкнот) достоинством в 10, 25, 50 и 100 рублей... Помимо банкнот в обращении находятся государственные казначейские билеты достоинством 1 , 3 и 5 рублей и мелкая металлическая разменная монета... Безналичные расчеты, осуществляемые в процессе обращения товаров, уменьшают потребность в денежных средствах» [16, с. 537]. Соответственно, денежная эмиссия трактуется как выпуск в обращение Госбанком дополнительного количества наличных денег по решениям правительства, а денежная масса - как масса только наличных денег в обращении - денег, проходящих через кассы Госбанка [16, с. 538]. Безналичные деньги не фигурируют в качестве их типа и в науке о деньгах и кредите, например 3.В.Атлас выделяет следующие исторические типы денег: товаро-счетный (украшения, меха, скот, рабы и т.д.), товаро-весовой (железо, медь, серебро, золото и т.д.), металло-чеканный и бумажно-эмиссионный (государственные бумажные деньги и банкноты) [2, с. 114-115]. Товарное производство в СССР трактовалось в этой науке как таковое особого рода, сфера действия которого ограничена предметами личного потребления [18, с. 37].

Покажем, что в середине 1950-х гг. СССР был близок к полной отмене банковской системы. В условиях безналичного обмена безболезненный переход в обществе к прямому обмену пред- полагает сохранение за прежней банковской системой части функций внешнего оператора платежно-кредитной системы, которая теперь становится безденежной. При этом в условиях, когда в стране формируется плановая (централизованная) система управления экономикой, что имело место в СССР, начиная с 1930-х гг., исполнение функций платежной и кредитной систем со временем может полностью перейти к самим участникам обмена и органам централизованного управления ими, т.е. внешний оператор платежно-кредитной системы, которым выступала формальная банковская система, окончательно отпадет.

Обоснованием полной отмены банковской системы здесь является, прежде всего, то, что по мере совершенствования системы отраслевого управления, составляющего основу централизованного управления, в том числе накопления им знаний, умений и компетенций, связанных с управлением денежными и кредитными потоками подотчетных организаций, двойное централизованное управление этими потоками - со стороны вышестоящих органов и со стороны банковской системы, уже не помогает централизованному управлению экономикой, а наносит ему вред. Об этом свидетельствует, в частности, отвергнутая руководством страны деструктивная реформа сферы денежного обращения и кредита, проталкивавшаяся Госбанком в 1940-1941 гг. На заседании Бюро Совета Народных Комиссаров СССР в начале января 1941 г. И.В.Сталин охарактеризовал проект Госбанка как мероприятие, толкающее страну не вперед, а назад, особенно удивляясь предложению о возрождении векселей, от которого недалеко и до требования учредить биржу. Выступивший после И. В. Сталина нарком финансов А. Г. Зверев сообщил, что, в частности, в результате введения краткосрочного кредита возродится автоматизм, который позволит предприятием по нескольку раз получать деньги на одни и те же цели, что ослабит контроль рублем, а банк, кредитуя оборот, получит контроль над формированием оборотных средств, представители банка будут вмешиваться в работ предприятий, зажимая инициативу их руководителей. Как отметил А.Г.Зверев, пункт об очередности платежей вообще подрывает госбюджет, гарантированность поступлений в первую очередь именно в него, что может нанести ущерб социалистическому воспроизводству, обороне страны и другим го- 
сударственным мероприятиям [8, с. 119-120].

При этом отраслевое управление, отмечая этот вред, мирится с вмешательством в управление подотчетными организациями банковской системы лишь потому, что она осуществляет такую функцию платежной системы, как обеспечение того, чтобы участники обмена не расходовали прав на получение товаров от общества больше, чем их у них имеется.

Другим обоснованием полной отмены банковской системы в условиях укрепления системы централизованного отраслевого управления является следующее:

1. По мере совершенствования деятельности по управлению на предприятиях в условиях централизованного управления ими подотчетные предприятия приобретают способность самостоятельно учитывать в текущем режиме получение и расходование ими товарных прав на основе товарных документов и документов на уступку и возврат прав, а также следить за тем, чтобы расходование ими прав осуществлялось в пределах их остатка, и главное - планировать соответствующее движение товарных прав.

2. Одновременно по мере совершенствования системы централизованного управления вышестоящие организации становятся способными обеспечить надежный контроль за соблюдением правил этой деятельности подотчетными предприятиями. В связи с этим внешний оператор платежной системы становится полностью ненужным. При его ликвидации исключается двойная работа в экономике по учету движения товарных прав, которая раньше осуществлялась вначале банковской системой (на основании предоставляемых ей документов), а затем (после получения выписок из лицевых счетов) дублировалась бухгалтериями предприятий. Кроме того, учет прав приближается во времени к моментам их возникновения и утраты, так как исключается прохождение документов через банк.

Сказанное в п. 1 подтверждается тем, что уже к концу 1930-х гг. появляются и начинают активно внедряться в практику управления методики оперативного планирования денежных и кредитных потоков на предприятиях и их оперативного учета и анализа, о чем говорит работа С.П.Днепровского (1939). В ней представлена таблица ежедневных поступлений и платежей по плану (составляемая на очередные 5 дней), в которую ежедневно записывается факт на ос- нове первичных документов (сдаточных квитанций, приходных квитанций и т.д.) с выведением отклонений (в целях текущего анализа) и остатка денег в кассе и на расчетном счете на каждое число [7, с. 291-292]. Естественно, график платежей составляется так, чтобы «...на каждый предстоящий день потребность в средствах для их оплаты не превышала среднедневной выручки...» [7, с. 290]. Таким образом, уже в конце 1930-х гг. советские предприятия могли сами вести свои расчеты с поставщиками, покупателями и т.д., следя за тем, чтобы использование прав на получение товаров от общества товары не превышало их остатка, сами контролировать свое кредитованием, о чем говорит наличие методики «анализа обеспеченности кредитов и расчетности по ним» [7, с. 270-273].

Сказанное в п. 2 подтверждается развитием периодического анализа хозяйственной деятельности предприятий, осуществляемого министерствами и главками, одним из разделов которого был анализ финансового положения, в том числе использование банковского кредита, осуществлявшегося как по данным отчетности, так и на основе всех учетных и внеучетных данных (при специальных обследованиях и ревизиях), о чем свидетельствует учебное пособие под ред. И. А.Шоломовича (1955) [1, с. 18, 358]. Из этой работы ясен параллелизм соответствующей деятельности вышестоящих органов и банковской системы, так как тот же периодический анализ осуществляют и финансово-банковские органы [1, с. 18]. В ней же утверждается, что контроль рублем (когда «...получение предприятием необходимых материальных и денежных средств поставлено в зависимость от выполнения планов производства и товарооборота» [1, с. 9], т.е. исполнение второй функции платежной системы), ранее считавшийся заботой банковской системы, теперь пронизывает всю систему взаимоотношений предприятий не только с банком и финансовыми учреждениями, но и с вышестоящими хозяйственными органами, утверждается, что именно контроль рублем делает необходимым систематическое изучение работы предприятий, систематический анализ их хозяйственной деятельности [1, с. 9].

В середине 1950-х гг. СССР был близок уже к полной отмене банковской системы. Об этом говорит то, что при И.В. Сталине шел неуклонный процесс совершенствования системы централизованного управления экономикой, связанный 
с развитием у предприятий и вышестоящих органов навыков по исполнению второй функции оператора платежной системы, который вскоре мог привести к соответствующему событию. О его близости свидетельствует выказанное И.В.Сталиным на октябрьском пленуме ЦК КПСС 1952 года мнение, что при сохранении прежних темпов экономического роста где-то в 1962-1965 гг. станет возможен переход от социализма к коммунизму, который начнется с ликвидации денег [9]. Полной ликвидации банков способствовали: 1) организационно - подчиненное положение в средине 1950-х гг. кредитной системы по отношению к Минфину [18, с. 11], то, что председатель Госбанка был замминистра финансов [5], 2) экономически - широкое развитие в СССР двухстороннего бартера, как разового (при отсутствии регулярных связей между предприятиями), так и, что особенно важно, систематического (когда предприятия регулярно поставляют друг другу продукцию и услуги), организацией которого занималось Бюро взаимных расчетов в структуре Госбанка (в 1951 г. расчеты посредством зачета взаимных требований достигли 37,6\% платежного оборота страны против 11,2\% в 1940 г. [18, с. 25]), 3) методологически - опыт полной ликвидации банковской системы (включая ЦБ) и официального перехода к прямому обмену в эпоху военного коммунизма [14], правда, без отказа от внешнего оператора платежной системы, роль которого в прямом обмене между национализированными предприятиями взяли на себя органы казначейства.

Однако после смерти И.В.Сталина в 1953 г. процесс совершенствования системы централизованного управления руководством страны был прерван, и взят устойчивый курс на ее постепенный демонтаж в виде предоставления госпредприятиям все большей и большей самостоятельности. Если при И.В. Сталине число показателей народнохозяйственного плана росло, то после его смерти оно стало быстро сокращаться (9490 в 1953 г., 6308 в 1954 г., 1780 в 1958 г.) [10, с. 255]. Уже в 1954-1955 гг. отчетность предприятий была значительно сокращена [1, с. 18]. В связи с этим полная отмена банковской системы лишилась перспективы. Укрепился и субъективный фактор. К ошибочному представлению о безальтернативности банковской системы при социализме, высказанному еще «ранним» К. Марксом (см. выше), добавилась незаинтересованность в отмене банковской системы советского чиновничьего класса, накопившего в зарубежных банках значительные суммы и не знавшего, как их использовать в СССР без банковской системы [9]. Да и вскоре закрылся сам путь в общество будущего, предполагающий подобные преобразования. Еще по инерции в конце 1950-х гг. экономика СССР продолжала расти опережающими темпами по сравнению с мировой, но затем началось ее отставание (рекордные 14,5\% мирового ВВП в 1960 г., 9,2\% - в 1990 г.), итогом которого стал крах советской экономики и распад страны [10, с. 254-255].

\section{Библиографический список}

1. Анализ хозяйственной деятельности предприятий: Учеб. пособие / под ред. И.А.Шоломовича.- М.: Госфиниздат, 1955. 360 с.

2. Атлас 3. В. Деньги и кредит (при капитализме и в СССР).- М.- Ленинград: Государственное издательство, 1930.459 c.

3. Бехер Э. Рабочий вопрос в его современном значении и средства к его разрешению с приложением уставов народного банка Прудона и уставов международной ассоциации рабочих / под ред. П.Н. Ткачева.- СПб.: Издание книжного магазина Черкесова, 1869-1871. 460 (VIII) с.

4. Будович Ю.И., Лебедев К. Н. Место финансов в современной экономике (Экономика без финансов) / под ред. К. Н. Лебедева.- Краснодар: Издательство НИИ экономики ЮФО, 2020. 187 с.

5. Василий Федорович Попов / Центральный банк Российской Федерации. URL: https://old.cbr.ru/today/history/ Popov/ (дата обращения: 21.03.2021).

6. Воловодова Е. В. Опыт использования локальных систем обмена услугами и товарами в кризисных условиях // Вестник Института экономических исследований. 2016. № 2. С. 58-65.

7. Днепровский С.П.Анализ и планирование хозяйственной деятельности сельпо.- М.: Госторгиздат, 1939. 296 с.

8. Зверев А.Г. Записки министра.-М.: Политиздат, 1973. 270 с.

9. Котин Д. Сталин - планировавший избавление от рабства денег / Проза.py. URL: https://proza. $\mathrm{ru} / 2018 / 01 / 13 / 2333$ (дата обращения: 21.03.2021). 
10. Лебедев К.Н. «Финансовый» характер собственности на средства производства в СССР и кризис советской экономики // Экономические науки. 2020. № 11 (192). С. 250-259. DOI: 10.14451/1.192.250.

11. Мадгазин В.Прудон - Теория банка обмена / Livejournal. 16.11.2011. URL: https://vadimrm.livejournal. com/136086.html (дата обращения: 30.01.2021).

12. Маркс К., Энгельс Ф. Сочинения. Издание второе. Том 13.- М.: Государственное издательство политической литературы, 1959. 771 (XXVI) с.

13. Маркс К., Энгельс Ф. Сочинения. Издание второе. Том 19.- М.: Государственное издательство политической литературы, 1961. 671 (XXVI) с.

14. Мельникова А.Деньги или «безденежные отношения»! / Pravo.studio. URL: https://pravo.studio/denejnyihsistem-istoriya/dengi-ilibezdenejnyie-otnosheniya.html (дата обращения: 28.01.2021).

15. Михаил Иванович Туган-Барановский. Пьер Жозеф Прудон / Его жизнь и общественная деятельность / Глава V / sensusnovus. Цех социальной мысли. URL: https://www.sensusnovus.ru/analytics/2014/11/26/19795.html (дата обращения: 27.01.2021).

16. Островитянов К.В., Шепилов Д. Т., Леонтьев Л. А., Кузьминов И. И. и др. Политическая экономия: Учебник.М.: Государственное издательство политической литературы, 1954. 639 с.

17. Оуэн Р. Избранные сочинения. Том I. Предшественники научного социализма / под общ. ред. В. П. Волгина.M.- Ленинград: Издательство Академии наук CCCP, MCML. 415 с.

18. Плотников К.Н. Кредит и денежное обращение в СССР: Лекции.- М.: Высшая партийная школа при ЦК КПСС, 1953, 52 с.

19. Туган-Барановский М.И. Общественно-экономические идеалы нашего времени.- СПб.: Издательство «Вестника знания» (В.В.Битнера), 1913. 143 с.

20. Эдвард Беллами и его утопия об американском социализме / Толкучка мыслей, фактов и суждений. 20.11.2014. URL: https://www.ttolk.ru/?p=22246 (дата обращения: 15.02.2021). 